\title{
The Impact of Oil Prices on the Economy of Vietnam
}

\author{
NGUYEN THI LIEN HOA \\ University of Economics HCMC - hoatcdn@ueh.edu.vn \\ TRAN THU GIANG \\ University of Economics HCMC - tranthu.giang@ueh.edu.vn \\ NGUYEN LE NGAN TRANG \\ University of Economics HCMC - trangnln@ueh.edu.vn
}

\section{ARTICLE INFO ABSTRACT}

Article history:

Received:

Jan. 152015

Received in revised form:

Jul. 242015

Accepted:

Sep. 152015

Keywords:

Oil prices, cointegration, error correction model.
In this paper we study the relationship between oil prices and macroeconomic performance by investigating the impact of oil price shocks on key macroeconomic variables of Vietnam over the 2001-2012 period. In order to test the relationship between oil prices and the value of industrial production, we use cointegration method to consider the long-term relationship and Error Correction Model (ECM) to ponder the short-term one. The test results show that the price of oil and the value of industrial production in Vietnam are positively correlated in the long term, whereas in the short term the volatility of oil prices in the last two months will negatively affect the fluctuation in the value of the current industrial production. 


\section{Introduction}

Today, the world economy depends mainly on the oil energy, and consumption of oil has increased constantly; therefore, crude oil plays a leading role as a key energy source for the world. Oil prices also have a huge impact on the development of the global economy because most industries are directly or indirectly dependent on this precious resource.

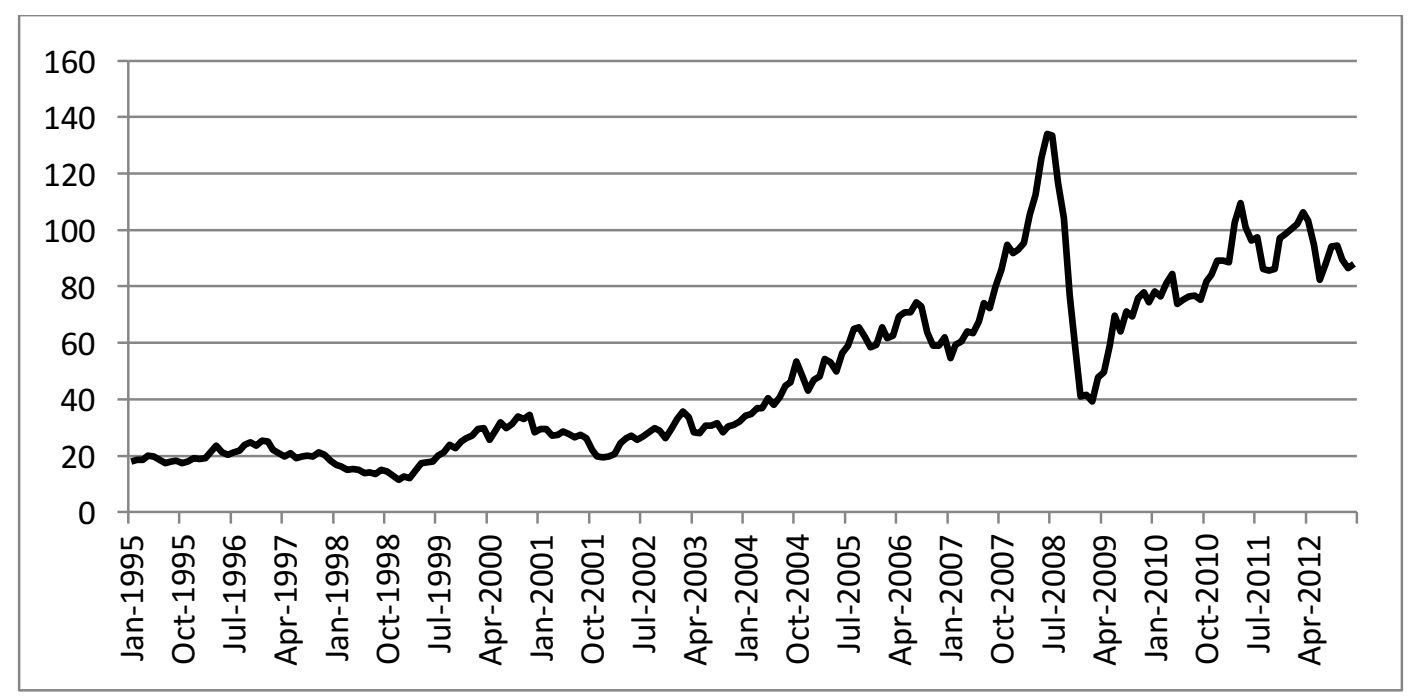

Figure 1. Crude oil prices between 1995 and 2012 (USD/barrel)

Source: Thomson Reuters

In the period from 1995 to 2005 oil prices doubled; however, the increase was relatively stable without large mutations. In contrast, from 2006 the prices of oil have always become hot news on the newspaper due to their erratic fluctuations. In particular, the year 2008 could be considered a historic year for oil prices when consecutive records were newly established every month. It was the time when the world economy experienced the events in full surprise, including a series of financial scandals and the collapse of many intermediaries.

From the macro perspectives, oil prices directly affect the revenues and costs of the country. On the one hand, Vietnam is the third largest crude oil exporter in the Southeast Asia (after Indonesia and Malaysia); on the other hand, Vietnam still has to import all gasoline until 2009. In February 2009, when Dung Quat oil refinery was operated, the first batch of gasoline was delivered; however, the dependence on importing oil is still 
very large. Particularly, oil prices in Vietnam are determined by not only the international market but also local government. Therefore, an increase and/or decrease in the price of oil should have a multi-dimensional impact on the economy of Vietnam.

Since Hamilton (1983), exploring oil prices and their increases accounting for postWorld War II US recessions, the oil price-macroeconomy nexus has been pinpointed by a range of studies, including Mork (1989), Hooker (1996), or Hamilton (1996), who documented that increasing oil prices leads to negative effects on growth, while oil price decline could have a small boost to GDP, besides Bernanke et al. (1997), Barsky and Kilian (2001), and Cologni and Manera (2008), who studied the effects of oil price shocks on monetary policy. Yet, there are few papers exploring the impact of oil prices on the macroeconomic performance of Vietnam (Narayan \& Narayan, 2010; Le \& Nguyen, 2011; Nguyen, 2014), and the research into the relationship between oil prices and the Vietnamese economy in both short and long terms is scarce.

This paper is organized as follows. Section 2 presents some literature reviews. Section 3 describes data and methodology, and empirical results are given in Section 4. The two final sections provide some concluding remarks and discuss a few recommendations to the oil market.

\section{Theoretical and empirical studies on the relationship between oil prices and the economy}

There are many studies exploring the relationship between oil prices and macroeconomic activities of the economy. In this section we focus on both theoretical and empirical research, investigating the impact of oil prices on the macroeconomic indicators.

\subsection{Transmission channels of oil price shocks}

According to Brown and Yucel (2002) and Tang et al. (2010), oil prices influence macroeconomic variables through many transmission channels as follows:

- The shock of the supply: the increase in the price of oil can be seen as an indicator of a supply shock to reduce potential output.

- Effect of transfer income and aggregated demand: oil price shocks can affect economic activities through the effects on a transfer of purchasing power from oil importing exporting countries in the event of rising oil prices. 
- The real monetary effect: higher oil prices will increase the demand for money. If monetary policy cannot boost the money supply to meet the increased demand, the interest rate will rise; hence, it will slow down the growth rate of the country. Similarly, oil prices may reduce investment because the manufacturer's profit decreases in this period, thereby reducing the demand for money.

- Inflationary pressure: the increase in oil price will create inflationary pressures in the economy.

- The role of monetary policy: in a certain period monetary policy will shape the way of the economy to absorb the oil price shocks.

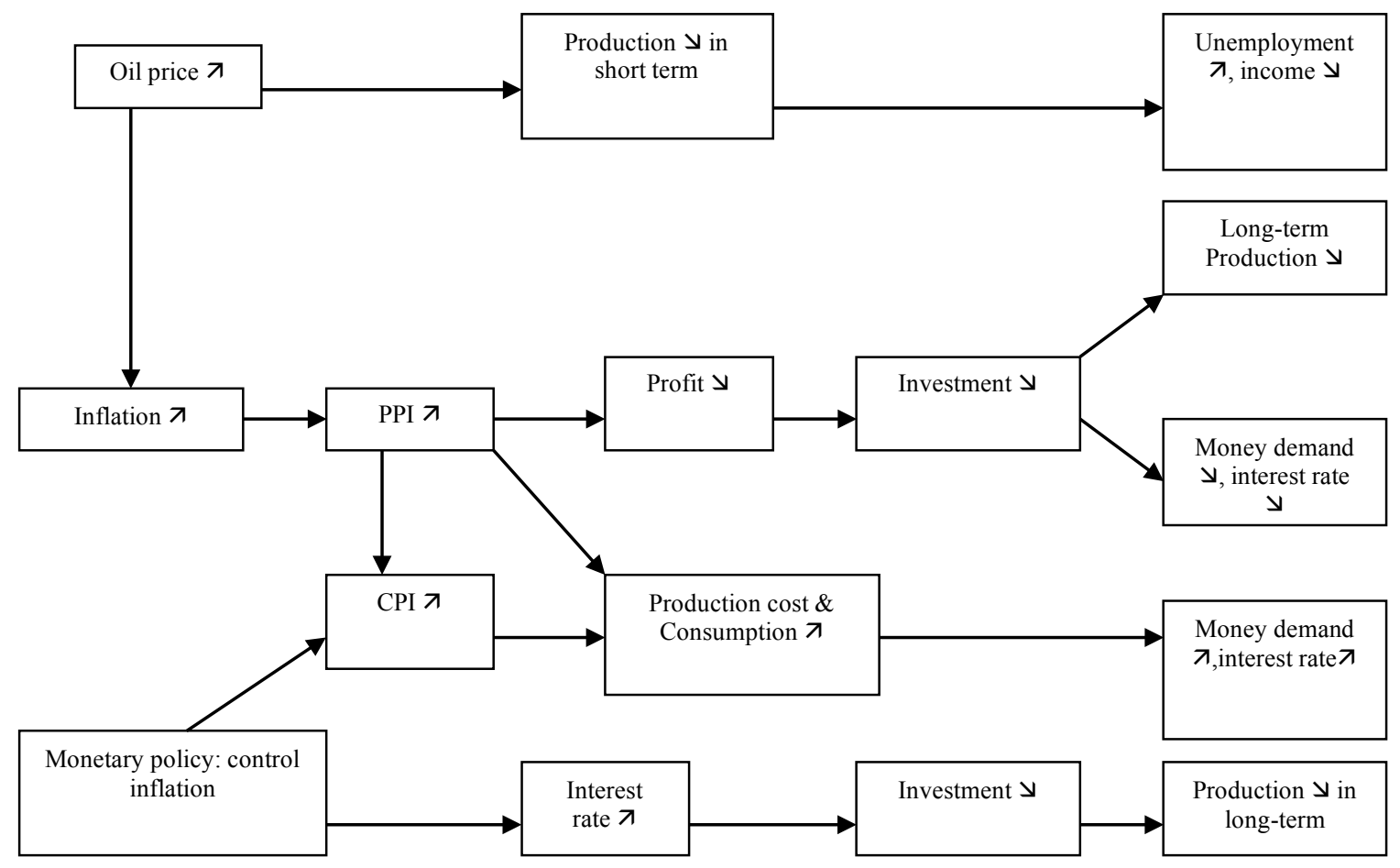

Figure 2. Diagram of the impact of oil price shocks on the economy

\subsection{Impact of oil prices on the economy}

The impact of oil prices on macroeconomic activities has become one of the most popular studied topics in energy economics from the mid-70s, after the oil crisis in 1973. A pioneer in this subject is Hamilton (1983). Using VAR methods proposed by Sim (1980) with US data over the period of 1948-1973, Hamilton (1983) concludes that the oil prices-US GNP growth relationship is negative, and seven to eight economic failures 
after the war periods in the United States occurred due to the significantly increasing crude oil prices.

Using the same period of time in their dataset, Gisser and Goodwin (1986) achieved similar results to Hamilton (1983). When analyzing the data on US growth during the period of 1949-1980, Hooker (1996) showed that if oil prices increased by $10 \%$, GDP fell by $0.6 \%$.

A few researches have been conducted to capture the relationship between oil prices and macroeconomic activities for the ASEAN countries. Using the data across 1975Q12002Q2, Cunado and de Gracia (2005) pointed out the oil price-economic activity nexus as well as the price indexes in some ASEAN countries (Japan, Singapore, South Korea, Malaysia, Thailand, and Philippines). They conclude that there exists no cointegration relationship in the long run. In short terms oil prices have Granger causal relationship with the growth of the economies of Japan, South Korea, and Thailand.

Tang et al. (2010) studied the short-term and long-term effects of the oil price in China, using SVAR model. They indicated that oil prices have a negative impact on product output and investment as well as the positive impact on inflation and interest rates.

However, few researches have ever been carried out into the impact of oil prices on economic activities in Vietnam. Narayan and Narayan (2010) was the first to explore the impact of oil prices on Vietnam's stock prices. Using data over the period of 2000-2008 including the nominal exchange rate as an additional determinant of stock prices, their results demonstrated the cointegration relationship between stock prices, oil prices, and the nominal exchange rate. In addition, the oil prices have a positive impact on the stock ones, which is inconsistent with theoretical expectations as caused by the internal and domestic factors.

\section{Research data and methodology}

We use monthly data over the period of 2001M1-2012M12. All data are in logarithm and seasonally adjusted by the Census X12 method, except for interest rate which is in percentage point at an annual rate. Details of the data are presented in Table 1, and all the variables included in the model are given in logarithmic forms. 


\section{Table 1}

Description of variables applied in the model

\begin{tabular}{|c|c|c|c|}
\hline Variable & & Description & Source \\
\hline Oil prices & OIL & $\begin{array}{l}\text { Crude oil (petroleum), price } \\
\text { index, } 2005=100 \text {, simple } \\
\text { average of three spot prices; } \\
\text { Dated Brent, West Texas } \\
\text { Intermediate, and the Dubai } \\
\text { Fateh }\end{array}$ & IMF \\
\hline $\begin{array}{l}\text { Industrial Production Index of } \\
\text { Vietnam }\end{array}$ & IPI & Index $(2005=100)$ & GSO \\
\hline $\begin{array}{l}\text { Consumer Price Index of } \\
\text { Vietnam }\end{array}$ & CPI & Index $(2005=100)$ & IMF \\
\hline $\begin{array}{l}\text { Nominal exchange rate of } \\
\text { Vietnam Dong }\end{array}$ & EX & Vietnam Dong per US dollar & IMF \\
\hline Real effective exchange rate & REER & $\begin{array}{l}\text { Bilateral exchange rates are } \\
\text { taken from DataStream and is } \\
\text { processed to calculate the } \\
\text { multilateral real exchange rate. }\end{array}$ & DataStream \\
\hline Money Supply M2 & M2 & $\begin{array}{l}\text { The change in the money } \\
\text { supply over the months; the } \\
\text { root month is January } 1,2002 \text {. }\end{array}$ & IMF \\
\hline
\end{tabular}

Note: REER is calculated based on currencies of 20 main trading partners of Vietnam, including Japan, Singapore, China, USA, South Korea, Australia, Thailand, Germany, Hong Kong, Malaysia, France, Indonesia, England, Netherland, Philippines, Italia, Switzerland, India, Spain, and Canada. The weight of each country in the overall trade volume of the country is $0.5 \%$.

In methodology we use analytical methods of cointegration (ECM) to estimate the relationship among the value of industrial production, oil prices, and other macroeconomic variables in the context of Vietnam as there are many variables in the model serving as non-stop time series. Moreover, this method also allows us to observe the relationship in both short and long terms.

Firstly, we start with the three most important variables: IP, CPI, and OIL. In order to test the relationships, we use the equation:

$$
\operatorname{Ln}(\mathrm{IPt})=\mathrm{a} 1+\mathrm{a} 2 \ln (\mathrm{OILt})+\mathrm{a} 3 \ln (\mathrm{CPIt})+\mathrm{ut}
$$


where IP is the value of industrial production, CPI is inflation index, OIL is oil prices, and ut represents the noise.

Because most of the variables could be non-stationary, causing the OLS approach to give spurious results, we conduct unit root tests. If the series in use become stationary at the same level I(1), it would be possible for the linear combination of the variables to be stationary at the zero level I(0), or in other words, the data are cointegrated. Johansen tests are further used to obtain the number of cointegrated vectors. Additionally, the results of these tests are used in the VECM technique, which measures the long-run relationship.

By its means the VECM is employed to identify the equilibrium or long-run relationship among the variables. The VECM form with the cointegration rank is written as:

$$
\Delta y_{t}=\Phi_{0}+\Pi y_{t-1}+\sum_{i=1}^{p} \Gamma_{i} \Delta y_{t-i}+\varepsilon_{t}
$$

where $\mathrm{y}$ is the variable matrices (IP is the value of industrial production; CPI is inflation index; OIL is oil prices $), \Phi_{0}$ is the explanatory vector $(3 \times 1), \varepsilon_{t}$ is white noise vector, $\Gamma$ is the coefficient matrices that proxy for the short-term relationship between the variables, whereas matric $\Pi$, the long-term relationship.

\section{Research results}

Unit root tests and cointegration tests

We use Augmented Dickey Fuller (ADF) to test for the existence of unit root. All the variables are found to be non-stationary in levels but stationary in first differences. The implication of this result is that we can examine evidence for any possible cointegration relationship between oil prices, industrial production index, and consumer price index in Vietnam. 


\section{Table 2}

Unit root tests

\begin{tabular}{ccc}
\hline \multirow{2}{*}{ Variable } & \multicolumn{2}{c}{ MacKinnon's (1996) one-sided p-values } \\
\cline { 2 - 3 } & Levels & First Differences \\
\hline OIL & 0.59 & 0.00 \\
EX & 0.98 & 0.00 \\
IPI & 0.48 & 0.00 \\
CPI & 0.99 & 0.00 \\
\hline
\end{tabular}

In order to identify the lag length of the model, we apply the usual Akaike's information criteria (AIC). According to AIC, as well as FPE, SC, and HQ criteria, the lag length should be set at two lags. At this lag length there is no serial correlations resulted from the LM test by Luiz and Mauro (2010). Therefore, the optimal lag length should be two.

\section{Table 3}

Lag-order selection criteria

\begin{tabular}{ccccccc}
\hline Lag & LogL & LR & FPE & AIC & SC & HQ \\
\hline 0 & 302.0600 & NA & $1.47 \mathrm{e}-07$ & -4.383235 & -4.297569 & -4.348423 \\
1 & 1148.834 & 1631.285 & $7.26 \mathrm{e}-13$ & -16.60050 & -16.17217 & -16.42643 \\
2 & 1190.464 & 77.75081 & $4.98 \mathrm{e}-13^{*}$ & $-16.97741^{*}$ & $-16.20642^{*}$ & $-16.66410^{*}$ \\
3 & 1206.050 & 28.19260 & $5.02 \mathrm{e}-13$ & -16.97133 & -15.85767 & -16.51876 \\
4 & 1216.913 & 19.00904 & $5.43 \mathrm{e}-13$ & -16.89577 & -15.43945 & -16.30396 \\
5 & 1231.357 & 24.42720 & $5.58 \mathrm{e}-13$ & -16.87289 & -15.07390 & -16.14183 \\
6 & 1248.103 & $27.33645^{*}$ & $5.56 \mathrm{e}-13$ & -16.88387 & -14.74221 & -16.01355 \\
7 & 1262.649 & 22.88832 & $5.73 \mathrm{e}-13$ & -16.86249 & -14.37816 & -15.85292 \\
8 & 1270.914 & 12.51909 & $6.51 \mathrm{e}-13$ & -16.74874 & -13.92175 & -15.59992 \\
\hline
\end{tabular}

To test for long-run relationship among the non-stationary variables, we perform the Johansen procedure. The results demonstrate the existence of cointegrating relationship 
between oil prices and domestic variables. Hence, a VECM model is employed to capture the long-run equilibrium (Lukepohl, 2005).

The results for both Trace statistic and Maximal Eigen statistic tests are reported in Table 4. Both trace and max-eigenvalue rank tests indicate that cointegration exists among the set of the variables at 5\% and 1\% levels of significance. Both trace and maximum-eigenvalue tests also suggest one cointegration vector, implying that long-run movements of the variables are determined by one equilibrium relationship

\section{Table 4}

Johansen tests for cointegration

\begin{tabular}{lcccc}
\hline \multicolumn{5}{c}{ Unrestricted Cointegration Rank Test (Trace) } \\
\hline $\begin{array}{c}\text { Hypothesized } \\
\text { No. of CE(s) }\end{array}$ & Eigenvalue & $\begin{array}{c}\text { Trace } \\
\text { Statistic }\end{array}$ & $\begin{array}{c}0.05 \\
\text { Critical Value }\end{array}$ & Prob.** \\
\hline None ${ }^{*}$ & 0.209067 & 52.09765 & 47.85613 & 0.0189 \\
At most 1 & 0.093530 & 19.02731 & 29.79707 & 0.4910 \\
At most 2 & 0.035963 & 5.181518 & 15.49471 & 0.7893 \\
At most 3 & 0.000123 & 0.017326 & 3.841466 & 0.8952 \\
\hline Unrestricted Cointegration Rank Test (Maximum Eigenvalue) & & \\
\hline Hypothesized & Eigenvalue & Max-Eigen & Critical Value & Prob.** \\
No. of CE(s) & 0.209067 & 33.07034 & 27.58434 & 0.0089 \\
None $*$ & 0.093530 & 13.84579 & 21.13162 & 0.3778 \\
At most 1 & 0.035963 & 5.164192 & 14.26460 & 0.7210 \\
At most 2 & 0.000123 & 0.017326 & 3.841466 & 0.8952 \\
At most 3 & & & \\
\hline
\end{tabular}




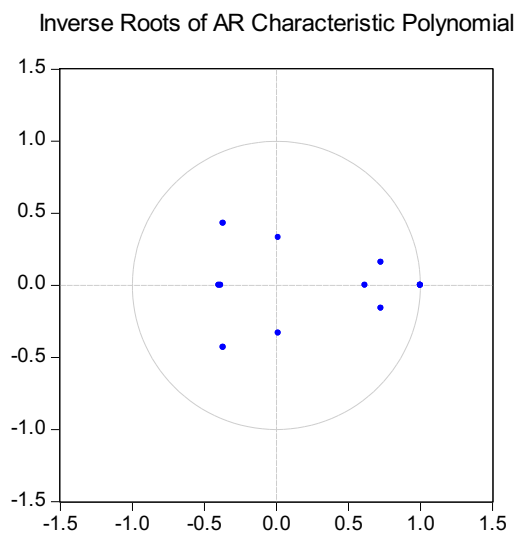

Figure 3. Eigen values stability circle

Based on Lutkepohl (2005), we check the stability of the model and find that no root lies outside the unit circle. This implies that our model satisfies the stability conditions.

Long-run relationship

We also base our procedure on Johansen's to construct the normalized cointegrating equation as follows:

$$
\text { LnIP }=8.826+0.22 \mathrm{LnOIL}+0.519 \mathrm{LnCPI}+0.013 \text { TREND }
$$

The normalized cointegrating equation shows that in the long run there is a negative relationship between oil price and industrial production index of Vietnam.

\section{Table 5}

Normalized cointegrating coefficient

\begin{tabular}{ccc}
\hline & \multicolumn{2}{c}{ Johansen } \\
\hline Variable & Coefficient & S.E \\
\hline LnIP & 1 & 0.065 \\
LnOIL & $-0.220^{* * *}$ & 0.254 \\
LnCPI & $-0.519^{* * *}$ & \\
C & -8.826 & 0.002 \\
Trend & $-0.013^{* * *}$ & \\
\hline
\end{tabular}

*Note: $* * *$, and $* * *$ denote significance levels of $10 \%, 5 \%$, and $1 \%$ respectively.

Short-run dynamics 
We then proceed with the VECM model for each set of variables to report the corresponding equation of each VECM associated with a particular oil price level. The VECMs provide the correction terms that reflect the effects of deviation of the relationship among the variables from long-run equilibrium and short-run parameters.

In the scope of this paper we present the adjustment coefficients related to DLNIP as follows:

\section{Table 6}

Vector error correction estimates/short-run dynamics

\begin{tabular}{|c|c|c|c|c|}
\hline \multirow{2}{*}{ DLNIP } & \multicolumn{2}{|c|}{ OLS } & \multicolumn{2}{|c|}{ JOHANSEN } \\
\hline & Coefficient & $\mathrm{Se}$ & Coefficient & $\mathrm{Se}$ \\
\hline $\mathrm{EC}(-1)$ & $-0.4498 * * *$ & 0.1400 & $-0.4799 * * *$ & 0.1367 \\
\hline D(LNIP(-1)) & $-0.3133^{* *}$ & 0.1466 & $-0.2965^{* *}$ & 0.1408 \\
\hline D(LNIP(-2)) & -0.1828 & 0.1392 & -0.1713 & 0.1330 \\
\hline D(LNIP(-3)) & -0.0727 & 0.1267 & -0.0745 & 0.1223 \\
\hline D(LNIP(-4)) & -0.0502 & 0.0992 & -0.0628 & 0.0980 \\
\hline DLNOIL & 0.0108 & 0.0442 & 0.0333 & 0.0446 \\
\hline DLNOIL(-1) & -0.0069 & 0.0116 & 8.88 & 0.0477 \\
\hline D(LNOIL(-2)) & -0.0660 & 0.0455 & $-0.0903 * *$ & 0.0459 \\
\hline D(LNOIL(-3)) & 0.0258 & 0.0461 & 0.0033 & 0.0467 \\
\hline D(LNOIL(-4)) & -0.0364 & 0.0447 & -0.0488 & 0.0456 \\
\hline DLNCPI & 0.3242 & 0.6623 & 0.2932 & 0.6238 \\
\hline D(LNCPI(-1)) & $1.2414^{*}$ & 0.6251 & 1.1714 & 0.6106 \\
\hline D(LNCPI(-2)) & 0.2143 & 0.6975 & 0.0431 & 0.6778 \\
\hline $\mathrm{D}(\mathrm{LNCPI}(-3))$ & $-1.2476^{*}$ & 0.6440 & $-1.6253 * * *$ & 0.6137 \\
\hline D(LNCPI(-4)) & -0.6869 & 0.6688 & -1.1083 & 0.6507 \\
\hline $\mathrm{C}$ & 0.0602 & 0.0645 & 0.0282 & 0.0072 \\
\hline R-squared & 0.435529 & & R-squared & 0.453600 \\
\hline Adjusted R-squared & 0.338206 & & Adj. R-squared & 0.359393 \\
\hline
\end{tabular}




\begin{tabular}{ccccc}
\hline \multirow{2}{*}{ DLNIP } & \multicolumn{2}{c}{ OLS } & \multicolumn{2}{c}{ JOHANSEN } \\
\cline { 2 - 5 } & Coefficient & Se & Coefficient & Se \\
\hline S.E. of regression & 0.036507 & & Sum sq. resids & 0.112236 \\
\hline
\end{tabular}

The results in Table 6 present the adjustment coefficient in connection with industrial production index of OLS and Johansen, respectively. The adjustment coefficients of EC are negative ( -0.4498 for OLS and -0.4844 for Johansen) and significant at $1 \%$ level. It means that the shocks of industrial production will make the adjustment to equilibrium, and this process will take around 2 to 2.2 months (corresponding to -0.4498 and 0.4844 ). In addition, the Johansen test shows that a negative relationship also exists between oil price and industrial production index.

\section{Impact of oil price shocks on domestic variables}

Theoretically, oil price shocks are expected to have negative effects on the economy through varying transmission mechanisms as mentioned above. However, our results indicate a positive response of domestic output to the shocks, which contradicts prior theories. However, in the context of Vietnam, a possible explanation for this relationship can be such that increasing oil prices may reflect the growth of developed countries. In such case the oil price shocks may involve increased exports as well as output of Vietnam.

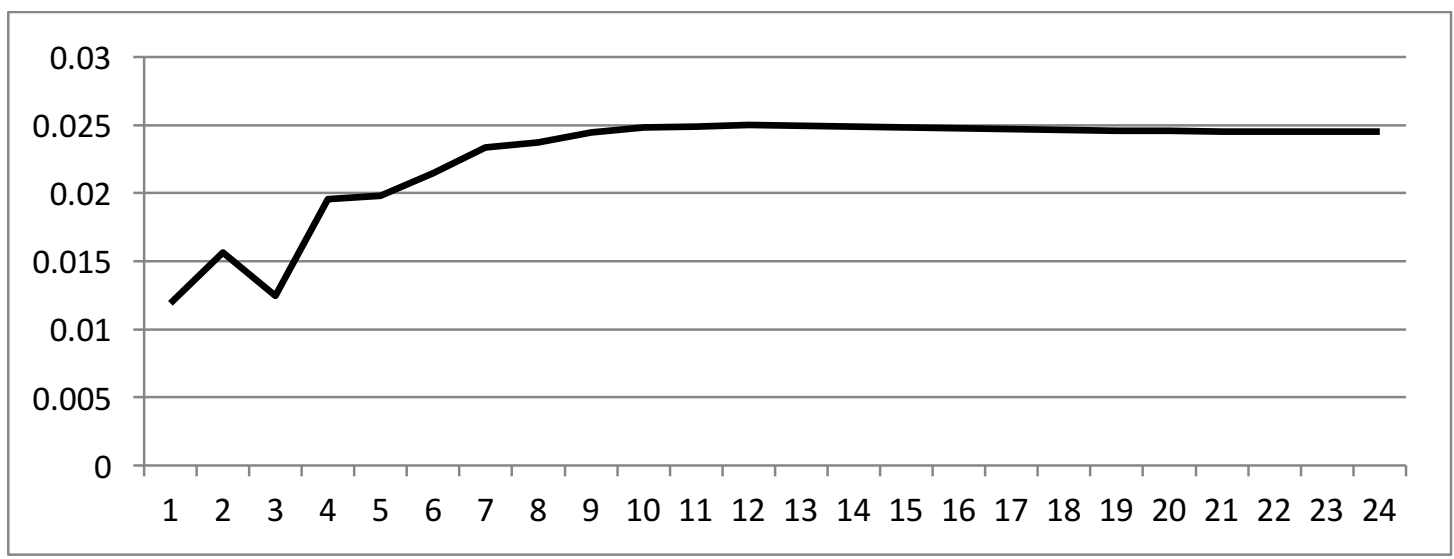

Figure 4. Impact of oil price shocks on output

Considering the fluctuations in domestic price level, oil price shocks exert significantly positive impacts on this macroeconomic variable. Those impacts are persistent, reflecting the importance of oil prices to price levels in Vietnam. This may 
be due to the country's high dependence upon gasoline and other kinds of oil-related products.

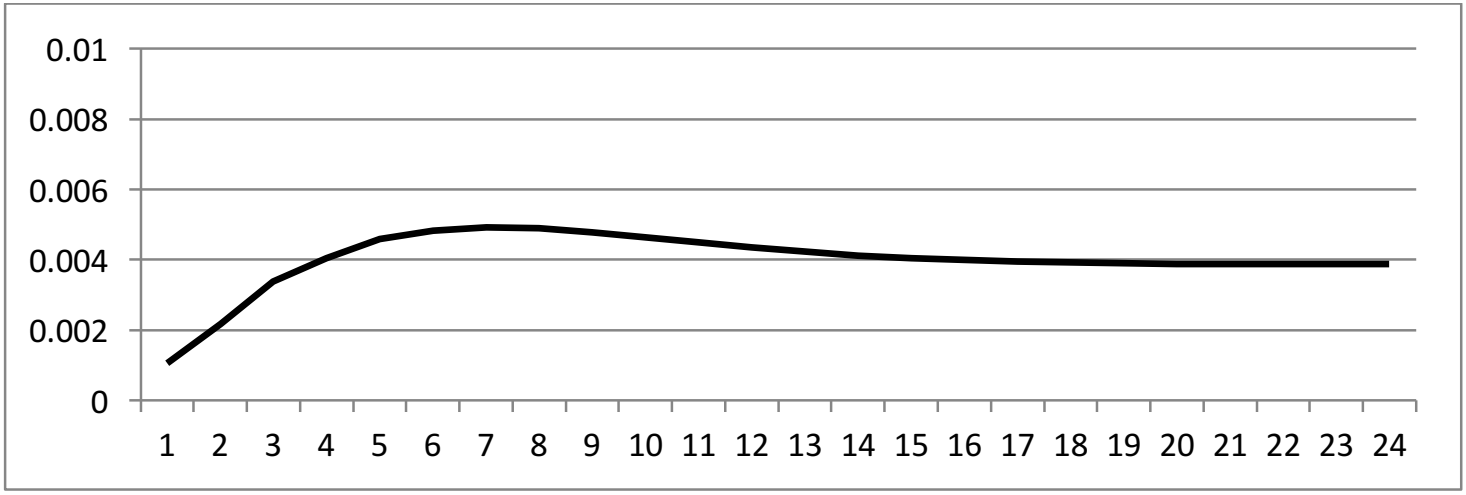

Figure 5. Impact of oil price shocks on price level

In contrast to domestic output and price level, the exchange rate remains unchanged by the oil price shocks. Its stability can be resulted from the stabilized arrangement regime adopted by The State Bank of Vietnam.

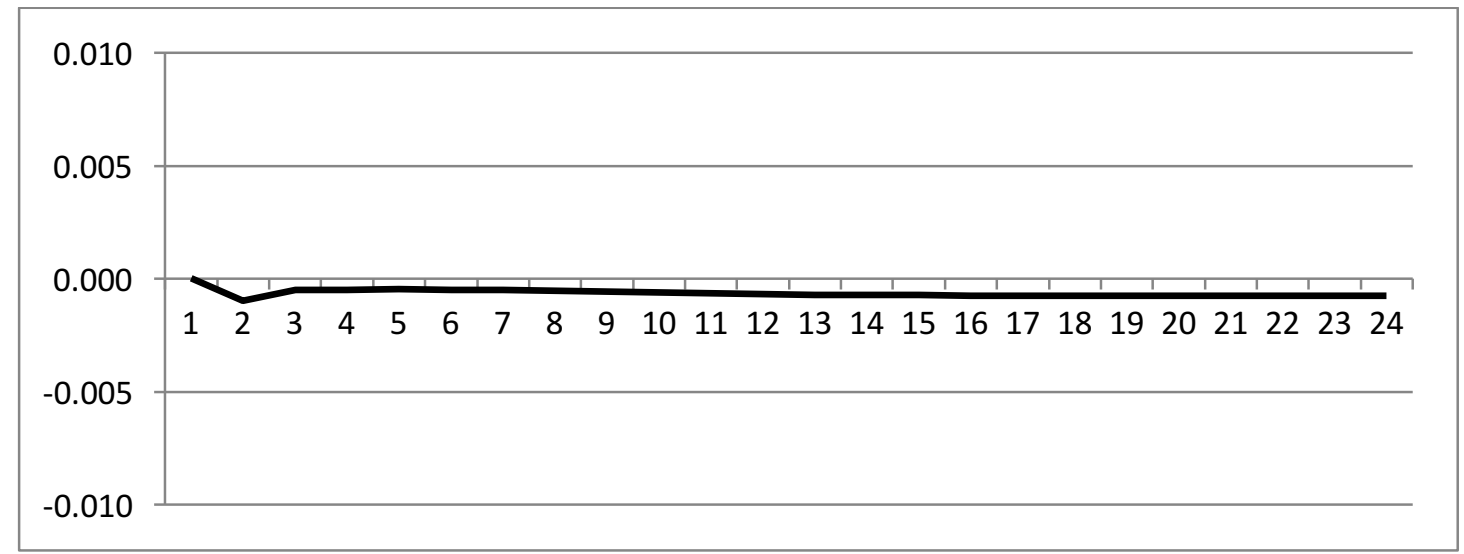

Figure 6. Impact of oil price shocks on exchange rate

\section{Importance of oil price shocks in variance of domestic variables}

In order to recognize the ability of oil price shocks to explain domestic variables fluctuations at different time horizons, we perform a standard variance decomposition of the forecast errors. Table 5 suggests the variance decomposition of the forecast error of domestic output. Oil price shocks seem to have a persistent impact as their weight in domestic output variances increases with time horizon. In the long run these external 
shocks account for approximately $20 \%$ of output variances, while the same figure for the other two domestic shocks is only $6 \%$.

\section{Table 7}

Variance decomposition of output

\begin{tabular}{ccccc}
\hline Period & OIL & EX & IPI & CPI \\
\hline 1 & 1.129923 & 0.003018 & 98.86706 & 0.000000 \\
2 & 2.870733 & 4.324768 & 92.49457 & 0.309932 \\
3 & 3.594429 & 4.471517 & 91.64795 & 0.286108 \\
4 & 5.448646 & 4.542069 & 89.61761 & 0.391672 \\
5 & 7.331573 & 5.087466 & 87.14914 & 0.431822 \\
6 & 9.190377 & 5.225545 & 85.15595 & 0.428123 \\
7 & 11.25348 & 5.389781 & 82.93613 & 0.420609 \\
8 & 13.18075 & 5.554160 & 80.86349 & 0.401599 \\
9 & 14.97172 & 5.636302 & 79.01332 & 0.378649 \\
10 & 16.63787 & 5.722520 & 77.28201 & 0.357610 \\
11 & 18.12555 & 5.790496 & 75.74444 & 0.339515 \\
12 & 19.45297 & 5.841727 & 74.38097 & 0.324337 \\
\hline
\end{tabular}

In the first six months oil price shocks account for more than $10 \%$ of domestic price level variances. However, this number decreases over time. In contrast, the output shocks have an increasing importance in forecasting domestic price level volatility, making them the most important shocks to the price level in long terms.

\section{Table 8}

Variance decomposition of price level

\begin{tabular}{ccccc}
\hline Period & OIL & EX & IPI & CPI \\
\hline 1 & 5.281161 & 0.056550 & 0.059120 & 94.60317 \\
2 & 8.226227 & 0.735418 & 0.472103 & 90.56625 \\
3 & 10.42450 & 0.318635 & 1.013366 & 88.24350 \\
4 & 11.18857 & 0.177146 & 1.929898 & 86.70439
\end{tabular}




\begin{tabular}{ccccc}
\hline Period & OIL & EX & IPI & CPI \\
\hline 5 & 11.42281 & 0.117413 & 3.145486 & 85.31429 \\
6 & 11.24257 & 0.085064 & 4.540183 & 84.13219 \\
7 & 10.85606 & 0.065645 & 5.989239 & 83.08905 \\
8 & 10.36562 & 0.052383 & 7.439632 & 82.14237 \\
9 & 9.850378 & 0.042811 & 8.812469 & 81.29434 \\
10 & 9.349095 & 0.035709 & 10.07762 & 80.53758 \\
11 & 8.884534 & 0.030376 & 11.21654 & 79.86855 \\
12 & 8.465673 & 0.026334 & 12.22405 & 79.28395 \\
\hline
\end{tabular}

The results of the nominal exchange rates reported in Table 7 are in line with the exchange rate regime of Vietnam. Other variables, both external and domestic, have an unimportant role in explaining the variance in exchange rates of Vietnam Dong.

\section{Table 9}

The variance decomposition of exchange rate

\begin{tabular}{ccccc}
\hline Period & OIL & EX & IPI & CPI \\
\hline 1 & $7.77 \mathrm{E}-05$ & 99.99992 & 0.000000 & 0.000000 \\
2 & 0.489379 & 99.32941 & 0.174323 & 0.006887 \\
3 & 0.429741 & 98.70543 & 0.554134 & 0.310696 \\
4 & 0.397289 & 97.96656 & 0.979659 & 0.656496 \\
5 & 0.366749 & 97.22320 & 1.362422 & 1.047630 \\
6 & 0.350792 & 96.38142 & 1.843164 & 1.424626 \\
7 & 0.340956 & 95.57760 & 2.301985 & 1.779459 \\
8 & 0.339483 & 94.81047 & 2.751067 & 2.098980 \\
9 & 0.343078 & 94.09635 & 3.181651 & 2.378925 \\
10 & 0.351039 & 93.45145 & 3.576857 & 2.620653 \\
11 & 0.361857 & 92.87262 & 3.937679 & 2.827846 \\
12 & 0.374350 & 92.35853 & 4.262649 & 3.004469 \\
\hline
\end{tabular}




\section{Concluding remarks}

In this paper we examine the relationship between oil prices and the three main macroeconomic variables of Vietnam. Theoretically, a rise in crude oil prices, on the one hand, increases exports, but on the other hand, leads to increased import prices. If the import costs are larger than the export revenues, oil price shocks will negatively affect the economy. However, our results indicate a positive impact of these external shocks on domestic output, implying the business cycle of Vietnam in the surveyed period. Additionally, the oil price shocks also result in an increase in domestic price levels and have an insignificant impact on the exchange rate of Vietnam.

The variance decomposition results show that oil prices account for approximately $20 \%$ of variance in output and only $10 \%$ of that in price levels. This can be subject to the Government's management of domestic market to protect the economy from adverse external shocks, which may include policies and subsidies for the establishment of the Petrol Price Stabilization Fund (PPSF). All of these supports also hint that there are many adverse conditions, which causes the pitfalls of monopoly in the oil industry. Specifically, the Petrolimex Group is accounted for more than $60 \%$ of the market share. Therefore, the Government must gain more control over the oil price in the market mechanism in order to prevent profiteering companies, predicted to negatively affect the health of the economy as well as people's lives.

\section{Recommendations to the oil market}

The Government may consider reducing the degree of monopoly in the industry. For example, Petrolimex can be split into separate companies in order to mitigate its monopoly power in import and export of gasoline. Moreover, researchers can develop derivative products to hedge the risks of gasoline prices in the Vietnamese market.

The Government shall reduce intervention into the petrol prices; even though energy security is a very important issue, petroleum consumption should be left to the market forces to decide on the prices. In addition, if gasoline subsidies are supposed to be made, these need to be implemented comprehensively and in balance. The increase in supply from domestic refineries, such as Dung Quat, is increasingly typical, which will help to stabilize and limit the disadvantages of oil price shocks in the economy. 
These solutions can be stylized into the variables to be tested. Simulation of oil price impact on the economy when these changes are made will help illustrate and quantify specific effects of each measure. This is also an extended direction for future research topics

\section{References}

Barsky, R. B., \& Kilian, L. (2001). Do we really know that oil caused the great stagflation? A monetary alternative (NBER Working Paper No. 8389). Cambridge, MA: National Bureau of Economic Research.

Bernanke, B. S., Gertler, M., \& Watson, M. (1997). Systematic monetary policy and the effects of oil price shocks. Brookings Papers on Economic Activity, No. 1, 91-157.

Brown, S. P. A., \& Yucel, M. K. (2002). Energy prices and aggregate economic activity: An interpretative survey. The Quarterly Review of Economics and Finance, 42(2), 193-208.

Cologni, A., \& Manera, M. (2008). Oil prices, inflation, and interest rates in a structural cointegrated VAR model for the G-7 countries. Energy Economics, 30(3), 856-888.

Cunado, J., \& de Gracia, F. P. (2005). Oil prices, economic activity, and inflation: Evidence for some Asian Countries. The Quarterly Review of Economics and Finance, 45(1), 65-83.

Gisser, M., \& Goodwin, T. (1986). Crude oil and the macroeconomy: Tests of some popular notions. Journal of Money, Credit and Banking, 18, 95-103.

Hamilton, J. D. (1983). Oil and the macroeconomy since World War II. Journal of Political Economy, 91, 228-248.

Hamilton, J. D. (1996). This is what happened to the oil price-macroeconomy relationship. Journal of Monetary Economics, 38(2), 215-220.

Hooker, M. A. (1996). What happened to the oil price-macroeconomy relationship? Journal of Monetary Economics, 38, 195-213.

Le, V. T., \& Nguyen, T. T. V. (2011). The impact of oil prices, real effective exchange rate, and inflation on economic activity: Novel evidence for Vietnam (Discussion Paper Series No. DP201109). Kobe, Japan: Research Institute for Economics and Business Administration, Kobe University.

Luiz, D. M., \& Mauro, P. (2010). The bank lending channel of monetary transmission in Brazil: A VECM approach. The Quarterly Review of Economics and Finance, 50, 50-60.

Lukepohl, H. (2005). New introduction to multiple time series analysis. Berlin, Germany: SpringerVerlag.

Mork, K. A. (1989). Oil and the macroeconomy when prices go up and down: An extension of Hamilton's results. Journal of Political Economy, 97, 740-744. 
Mory, J. F. (1993). Oil prices and economic activity: Is the relationship symmetric? Energy Journal, 14, 151-161.

Narayan, P. K., \& Narayan, S. (2010). Modelling the impact of oil prices on Vietnam's stock prices. Applied Energy, 87(1), 356-361.

Nguyen, V. C. (2014). Impacts of international oil price changes on Vietnam's economy: An input and output study. Asian Economic and Financial Review, 4, 432-439.

Tang, W., Wu, L., \& Zhang, Z. (2010). Oil price shocks and their short- and long-term effects on the Chinese economy. Energy Economics, 32, S3-S14. 